Terbit online pada laman : http://teknosi.fti.unand.ac.id/

Jurnal Nasional Teknologi dan Sistem Informasi

ISSN (Print) 2460-3465 | ISSN (Online) 2476-8812 |

Artikel Penelitian

\title{
Implementasi Metode Simple Additive Weighting Dalam Penentuan Sekolah Dasar Negeri Rujukan/Model Kota Jambi
}

\author{
Novhirtamely Kahar ${ }^{a,}{ }^{*}$, Retno Palupi ${ }^{b}$ \\ ${ }^{a, b}$ Teknik Informatika STMIK Nurdin Hamzah Jambi, Jln. Kolonel Abunjani Sipin, Jambi 36121, Indonesia
}

\section{INFORMASI ARTIKEL}

Sejarah Artikel:

Diterima Redaksi: 15 November 2019

Revisi Akhir: 08 Januari 2020

Diterbitkan Online: 12 Januari 2020

\section{KATA KUNCI \\ Sekolah Dasar Negeri Rujukan/Model, \\ Simple Additive Weighting, \\ Rating Kecocokan}

KORESPONDENSI

E-mail: novmely@ymail.com

\begin{abstract}
A B $\mathbf{S} \quad \mathbf{T} \quad \mathbf{R}$ A $\mathbf{C}$ T
Sekolah Dasar Negeri (SDN) Rujukan/Model merupakan sekolah rujukan pelyanan pendidikan yang bermutu dan memiliki program unggulan tersendiri. SDN rujukan/model di Kota Jambi masih sangat minim, sehingga sering terjadi di suatu SDN rujukan/model jumlah pendaftar melebihi formulir atau kuota yang tersedia pada SD favorit. Hal ini menyebabkan SDN yang bukan rujukan/model justru kekurangan murid. Penentuan SDN Rujukan/Model selama ini masih dilakukan secara konvensioal (belum menggunakan sistem terkomputerisasi) sehingga dirasa lambat. Penelitian ini bertujuan untuk membangun aplikasi Sistem Pendukung Keputusan penentuan SDN rujukan/model dengan metode Simple Additive Weighting (SAW) yang dapat membantu pihak Dinas Pendidikan Kota Jambi dalam menentukan SD rujukan/model setiap tahunnya, sehingga dapat mempercepat proses penentuan dan dapat meningkatkan jumlah SDN rujukan/model di Kota Jambi. Data penentuan SDN rujukan/model berupa data sekolah, data kriteria, data sub kriteria, rating kecocokan dan akan menghasilkan output yaitu perangkingan dan laporan dalam bentuk pdf dan grafik menggunakan bahasa pemograman php dan database MySQL. Hasil perhitungan dengan metode SAW, menunjukkan nilai terbesar yang dipilih sebagai Sekolah Dasar Rujukan/Model adalah SD Negeri 053 IV Jambi.
\end{abstract}

\section{PENDAHULUAN}

Pendidikan Sekolah Dasar (SD) sebagai jenjang paling dasar pendidikan formal mempunyai peran besar bagi keberlangsungan proses pendidikan selanjutnya[1]. Oleh karenya Pemerintah pusat dan pemerintah daerah wajib memberikan pelayanan yang bermutu mengacu pada standar nasional pendidikan, berdasarkan pada Undang-Undang Nomor 20 Tahun 2003 tentang Sistem Pendidikan Nasional Pasal 11. Pengembangan SD rujukan/model mengarah pada terselenggaranya layanan pendidikan dasar yang berkualitas melalui pemenuhan 8 Standar Nasional Pendidikan (SNP). SD rujukan/model diharapkan menjadi contoh bagi sekolah lain dalam pengembangan pengetahuan dan pelaksaan praktik-praktik yang baik (best practices), seperti manajemen, penataan lingkungan sekolah, sarana dan prasarana yang menujang proses KBM, dan kegiatan pembiasaan sebagai penguatan pendidikan karakter siswa. Selanjutnya sekolah inilah yang nantinya diharapkan mampu menjadi pelopor pelaksana kebijakan, pengembang keunggulan dan keunikan sehingga dapat menjadi rujukan bagi Sekolah Dasar Negeri yang lain.

Sekolah model adalah sekolah yang ditetapkan oleh pemerintah dan dibina oleh Lembaga Penjamin Mutu Pendidikan (LPMP) untuk menjadi sekolah acuan bagi sekolah lain di sekitarnya dalam penerapan penjaminan mutu pendidikan secara mandiri. Sekolah model menerapkan seluruh siklus penjaminan mutu pendidikan secara sistematik, holistic, dan berkelanjutan, sehingga budaya mutu tumbuh dan berkembang secara mandiri pada sekolah tersebut [2].

Dari 188 SDN di Kota Jambi, jumlah SDN rujukan/model sangat minim yaitu hanya sekitar $5 \%$ saja yang menjadi sekolah rujukan/model. Hal tersebut tentu saja menyebabkan sering terjadi masalah dimana suatu SDN rujukan/model jumlah pendaftar siswa baru melebihi formulir dan kuota yang tersedia, karena kebanyakan orang tua menginginkan anaknya sekolah di tempat yang bermutu 
atau berkualitas. Sedangkan untuk sekolah yang bukan rujukan, justru jumlah siswa yang mendaftar tidak mencapai kuota. Masalah lainnya adalah, proses penentuan SDN rujukan/model selama ini belum maksimal, masih menggunakan cara yang belum terkomputerisasi, sehingga proses penentuan SDN rujukan/model memakan waktu yang lama. Selain itu untuk menghindari masalah ketimpangan dalam penjaminan mutu sesuai dengan tingkat kelayakan sekolah untuk dijadikan sekolah model.

Dibutuhkan adanya suatu sistem yang terkomputerisasi, yaitu aplikasi sistem pendukung keputusan penentuan SDN rujukan/model di Kota Jambi. Penelitian ini bertujuan untuk membangun aplikasi sistem pendukung keputusan berbasis web dengan mengimplementasikan metode SAW dalam menentukan SDN rujukan/model di Kota Jambi sehingga bisa menjadi alat bantu bagi Dinas Pendidikan Kota Jambi dalam proses penentuan SDN rujukan/model di Kota Jambi dan agar penetapan SDN rujukan/model lebih obyektif dan transparan.

Penelitian sejenis tentang sekolah model telah dilakukan pada penelitian sebelumnya oleh Saifuddin dan Abdullah yang berjudul "Sistem Pendukung Keputusan Pembinaan dan Pengembangan Sekolah Model (Studi Kasus Kecamatan Kempas)”. Penelitian ini bertujuan untuk membangun suatu sistem pengambilan keputusan dalam pembinaan dan pengembangan sekolah model dalam mengambil suatu keputusan yang baik yang sesuai dengan tingkat kelayakan sekolah untuk dijadikan sekolah model, dalam hal ini adalah tingkat Sekolah Menengah Pertama Negeri (SMPN) [2]. Metode yang diterapkan adalah metode Analytical Hierarchi Process (AHP), yaitu metode yang mencari nilai bobot setiap atribut, kemudian dilakukan perangkingan yang akan menentukan altrnatif yang optimal, yaitu SMPN model. Pada penelitian ini hanya menggunakan 3 kriteria, yaitu: Sekolah memenuhi SNP (Standar Nasioanal Pendidikan), Komitmen seluruh komponen sekolah, dan Dukungan dari pemerintah daerah.

Penggunaan metode SAW pada penenlitian sejenis sebelumnya dilakukan oleh Agus Supriyadi dengan judul "Sistem Penunjang Keputusan Pemilihan Sekolah Dasar Terbaik Dengan Metode Simple Additive Weighting (SAW) (Studi Kasus: Unit Pelaksana Teknis Daerah (UPTD) Kecamatan Cilandak)". Penelitian ini bertujuan membangun sistem penunjang keputusan (SPK) untuk dapat mempermudah penilaian pemilihan Sekolah Dasar terbaik pada Kecamatan Cilandak [3]. Kriteria yang digunakan yaitu ada 3 sesuai dengan SOP (Standar Operational Procedure) yang berlaku: Standar kelulusan, Sarana dan prasaran, serta akreditasi.

Oleh karena itu peneliti tertarik untuk dapat dilakukan penelitian selanjutnya dengan menambahkan kriteria penilaian SDN rujukan/model dan mengembangkan aplikasi menjadi berbasis web dikarenakan saat ini adalah era pemanfaatan dan penggunaan aplikasi berbasis online.

Dengan adanya penelitian ini dapat memberikan manfaat bagi pengembangan ilmu pengetahuan, yaitu: menambah ilmu pengetahuan khususnya di bidang pendidikan sekolah dasar, dimana aplikasi sistem pendukung keputusan berbasis komputer yang dibangun dapat membantu pihak sekolah untuk tertib administrasi khususnya pelaporan kegiatan dan mutu sekolah dasar kepada pihak dinas pendidikan setiap tahunnya, sehingga pihak dinas pendidikan dapat lebih mudah dan cepat dalam menilai mutu suatu sekolah dasar dan secara rutin melakukan penilaian kinerja sekolah dasar untuk memilih sekolah dasar yang dapat dijadikan rujukan/model.

Selain itu juga, dengan penelitian sistem pendukung keputusan dengan metode SAW yang dibangun ini dapat menambahkan sumber referensi bagi penelitian selanjutnya khususnya penerapan SAW di bidang pendidikan dan dapat juga digunakan sebagai bahan analisis perbandingan dengan metode lainnya.

\section{METODE}

\subsubsection{Objek Penelitian}

Penelitian dilakukan di Dinas Pendidikan Kota Jambi yang mempunyai fungsi salah satunya melakukan pengawasan terhadap kinerja SDN yang ada di Kota Jambi.

\subsubsection{Kebutuhan Data}

Data yang dibutuhkan untuk melakukan penelitian membangun aplikasi SPK SDN rujukan/model ini adalah data yang diperoleh langsung dari tempat penelitian dan data yang diperoleh dengan mempelajari literatur baik yang bersumber dari media cetak maupun media elektronik. Data bersumber dari tempat penelitian, yaitu:

a. Data SDN di Kota Jambi sebagai alternatif.

b. Data kriteria penentuan SDN rujukan/model, terdiri dari: Kurikulum, Akreditasi, Model, Prestasi, Integritas Indeks UN, Terjangkau, Inovasi, dan Inovator/Praktek.

c. Data subkriteria setiap kriteria.

d. Data bobot kriteria, yaitu data nilai berdasarkan kriteria yang dipilih.

\subsubsection{Kebutuhan Proses}

Kebutuhan proses pada aplikasi SPK SDN rujukan/model yang akan dibangun adalah:

a. Proses olah data alternative

b. Proses olah data kriteria dan subkriteria

c. Proses olah data bobot kriteria dan bobot subkriteria

d. Proses olah data proses perangkingan

e. Proses oleh data laporan

\subsubsection{Kebutuhan Output}

Kebutuhan output pada penelitian ini adalah:

a. Laporan data perangkingan hasil penilaian SDN rujukan/model per sekolah.

b. Laporan keseluruhan hasil perangkingan 


\subsection{Model Sistem Pendukung Keputusan}

Sistem pendukung keputusan adalah sistem berbasis komputer interaktif yang membantu pengguna dalam penilaian dan pemilihan. Sistem tidak hanya menyediakan penyimpanan dan pengambilan data tapi juga meningkatkan akses informasi tradisional dengan dukungan untuk pembuatan model pengambilan keputusan dan penalaran berbasis model [4].

Beberapa model algoritma pendukung keputusan diantaranya model: Sistem Pakar, Analytical Hierarchy Process (AHP), Fuzzy Multiple Attribute Decision Making (FMADM), dan Simple Additive Weighting (SAW) [5].

\subsection{Model Simple Additive Weighting (SAW)}

Metode SAW sering juga dikenal istilah metode penjumlahan terbobot. Metode ini merupakan metode yang paling terkenal dan paling banyak digunakan dalam menghadapi situasi Multiple Attribute Decision Making (MADM). MADM itu sendiri merupakan suatu metode yang digunakan untuk mencari alternatif optimal dari sejumlah alternatif dengan kriteria tertentu. Metode SAW ini mengharuskan pembuat keputusan menentukan bobot bagi setiap atribut. Skor total untuk alternatif diperoleh dengan menjumlahkan seluruh hasil perkalian antara rating (yang dapat dibandingkan lintas atribut) dan bobot tiap atribut. Rating tiap atribut haruslah bebas dimensi dalam arti telah melewati proses normalisasi matriks sebelumnya [6].

Langkah penyelesaian SAW adalah sebagai berikut:

a. Menentukan kriteria-kriteria yang akan dijadikan acuan dalam pengambilan keputusan, yaitu Ci.

b. Menentukan rating kecocokan setiap alternatif pada setiap kriteria.

c. Membuat matriks keputusan berdasarkan kriteria(Ci), kemudian melakukan normalisasi matriks berdasarkan persamaan yang disesuaikan dengan jenis atribut (atribut keuntungan ataupun atribut biaya) sehingga diperoleh matriks ternormalisasi $\mathrm{R}$ Rumus normalisasi:

$$
r_{i j}=\left\{\begin{array}{c}
\frac{x_{i j}}{\operatorname{Max} x_{i j}}, \text { Jika } j \text { atribut keuntungan (benefit) } \\
\frac{\text { Min } x_{i j}}{x_{i j}}, \text { Jika } j \text { atribut biaya }(\text { cost })
\end{array}\right.
$$

d. Hasil akhir diperoleh dari proses perankingan yaitu penjumlahan dari perkalian matriks ternormalisasi $\mathrm{R}$ dengan vektor bobot sehingga diperoleh nilai terbesar yang dipilih sebagai alternatif terbaik (Ai) sebagai solusi.

Rumus Nilai preferensi untuk setiap alternative (Vi):

$$
V_{i}=\sum_{j=1}^{n} w_{j} r_{i j}
$$

Nilai $V_{i}$ yang lebih besar mengindikasikan bahwa alternatif $A_{i}$ lebih terpilih.

\subsection{Kriteria SDN Rujukan/Model di Kota Jambi}

Ada Beberapa kriteria-kriteria Sekoah Dasar Rujukan/Model sebagai acuan bagi Dinas Pendidikan Kota Jambi dalam menentukan SDN rujukan/model sebagai berikut [7]:

a. Melaksanakan Kurikulum 2013, merupakan kriteria mutlak untuk menjadi sekolah rujukan, dengan subkriteria berikut:

Tabel 1. Sukbriteria Kriteria Kurikulum

\begin{tabular}{cccc}
\hline Jenis Kurikulum & Nilai & Keterangan & Bobot $(\mathbf{W})$ \\
\hline 2013 & 100 & Sangat Baik & 5 \\
2009 & 75 & Baik & 4 \\
2006 & 50 & Cukup & 3 \\
\hline
\end{tabular}

b. Memiliki Akreditasi A atau tertinggi se kota/kabupaten, dengan subkriteria berikut:

Tabel 2. Subkriteria Kriteria Akreditasi

\begin{tabular}{cccc}
\hline Nilai Akreditasi & Nilai & Keterangan & Bobot $(\mathbf{W})$ \\
\hline A & 100 & Sangat Baik & 5 \\
B & 75 & Baik & 4 \\
C & 50 & Cukup & 3 \\
\hline
\end{tabular}

c. Pernah menjadi sekolah model, yaitu pernah menjadi sekolah acuan bagi sekolah lain disekitarnya dalam penerapan peminjaman mutu pendidikan secara mandiri, dengan subkriteria berikut:

Tabel 3. Subkriteria Kriteria Model

\begin{tabular}{cccc}
\hline Model & Nilai & Keterangan & $\begin{array}{c}\text { Bobot } \\
(\mathbf{W})\end{array}$ \\
\hline Pernah & 100 & Sangat Baik & 5 \\
Tidak Pernah & 75 & Baik & 4 \\
\hline
\end{tabular}

d. Memiliki praktik baik dan inovasi pendidikan, setidaknya didalam sekolah tersebut memiliki berbagai macam inovasi pendidikan, baik berupa metode, media, dan modul pembelajaran yang mana terintegrasi dengan teknologi dan digital, dengan subkriteria berikut:

Tabel 4. Subkriteria Kriteria Praktik Baik dan Inovasi

\begin{tabular}{cccc}
\hline Nilai Inovasi & Nilai & Keterangan & Bobot $(\mathbf{W})$ \\
\hline $80-100$ & 100 & Sangat Baik & 5 \\
$60-80$ & 75 & Baik & 4 \\
$0-60$ & 50 & Cukup & 3 \\
\hline
\end{tabular}

e. Memiliki prestasi akademik dan non akademik, baik itu di tingkat kota/kabupaten, tingkat provinsi, tingkat nasional bahkan tingkat internasional, dengan subkriteria berikut:

Tabel 5. Subkriteria Kriteria Prestasi

\begin{tabular}{cccc}
\hline Prestasi & Nilai & Keterangan & Bobot $(\mathbf{W})$ \\
\hline Akademik & 100 & Sangat Baik & 5 \\
Non Akademik & 75 & Baik & 4 \\
\hline
\end{tabular}

f. Memiliki akses yang mudah untuk dijangkau, dari segi geografis dan ekosistem (guru, karyawan, dan peserta didik) 
sekolah berjalan dengan baik dan nyaman, dengan subkriteria berikut:

Tabel 6. Subkriteria Kriteria Terjangkau

\begin{tabular}{cccc}
\hline Jarak & Nilai & Keterangan & Bobot $(\mathbf{W})$ \\
\hline Dekat & 100 & Sangat Baik & 5 \\
Sedang & 75 & Baik & 4 \\
Jauh & 50 & Cukup & 3 \\
\hline
\end{tabular}

g. Mempertimbangkan nilai UAN dan Nilai Integritas Ujian Nasional (IIUN) yang bersangkutan, sekolah harus mampu memprediksi hasil nilai peserta didik agar bisa mengarahkannya ke jenjang pendidikan yang lebih tinggi, dengan subkriteria berikut:

Tabel 7. Subkriteria Kriteria UAN dan IIUN

\begin{tabular}{cccc}
\hline Nilai UAN/IIUN & Nilai & Keterangan & Bobot $(\mathbf{W})$ \\
\hline $80-100$ & 100 & Sangat Baik & 5 \\
$60-80$ & 75 & Baik & 4 \\
$0-60$ & 50 & Cukup & 3 \\
\hline
\end{tabular}

h. Bersedia memberikan pengimbasan praktik baik dan inovasi pendidikan yang dimiliki ke sekolah lain (Inovator), dengan subkriteria berikut:

Tabel 8. Subkriteria Kriteria Inovator

\begin{tabular}{cccc}
\hline Nilai Inovator & Nilai & Keterangan & Bobot $(\mathbf{W})$ \\
\hline $80-100$ & 100 & Sangat Baik & 5 \\
$60-80$ & 75 & Baik & 4 \\
$0-60$ & 50 & Cukup & 3 \\
\hline
\end{tabular}

Nilai bobot untuk subkriteria adalah seperti terlihat di Tabel 9:

Tabel 9. Nilai Bobot Kriteria

\begin{tabular}{ccc}
\hline Nilai Kriteria (C) & Bobot (\%) & Keterangan \\
\hline 1 & 5 & Sangat Baik \\
2 & 4 & Baik \\
3 & 3 & Cukup \\
\hline
\end{tabular}

\subsection{Gap Analysis}

Gap analisys atau analis kesenjangan merupakan salah satu langkah yang sangat penting dalam tahapan perencanaan maupun tahap evaluasi kerja. Metode ini merupakan salah satu metode yang paling umum digunakan dalam pengelolaan manajemen internal suatu lembaga. Secara harfiah "gap" mengidentifikasikan adanya suatu perbedaan (disparity) antara satu hal dengan hal lainnya[8]

Pendekatan yang digunakan untuk menilai kinerja Sekolah Dasar Negeri Rujukan/Model adalah menggunakan metoda Gap Analisis. Gap dihitung berdasarkan formula sederhana sebagai berikut :

Gap $=$ Profil SDN Rujukan/Model - Profil Standar

Profil SDN Rujukan/Model merupakan nilai bobot setiap subkriteria kriteria untuk setiap sekolah. Sedangkan Profil Standar adalah ditentukan berdasarkan kesepakatan manajemen dan pengambil kebijakan.
Langkah/tahapan gap analysis:

1. Penentuan bobot setiap kriteria

Core Facto, 60\%r: Kurikulum, Prestasi, Akreditasi

Secondary Factor, 40\%: Indeks UAN dan IIUN, Inovasi, Model, Inovator, Terjangkau.

2. Penentuan skor setiap sub kriteria

Seperti telihat pada Tabel 1 s.d Tabel 8.

3. Pemetaan Gap, menghitung nilai gap setiap kriteria untuk setiap alternatif, seperti pada rumus (3).

4. Pemetaan nilai perhitungan gap dengan nilai bobot sesuai tabel 10 .

Tabel 10. Bobot Nilai Gap

\begin{tabular}{|c|c|c|c|c|c|}
\hline No & $\begin{array}{l}\text { Seli- } \\
\text { sih }\end{array}$ & $\begin{array}{l}\text { Bobot } \\
\text { Nilai }\end{array}$ & Keterangan & & \\
\hline 1 & 0 & 6 & $\begin{array}{l}\text { Tidak ada selisih (kor } \\
\text { dengan yang dibutuhkan }\end{array}$ & npetensi sesi & \\
\hline 2 & 1 & 5,5 & $\begin{array}{l}\text { Kompetensi individu } \\
\text { tingkat/level }\end{array}$ & kelebihan & 1 \\
\hline 3 & -1 & 5 & $\begin{array}{l}\text { Kompetensi individu } \\
\text { tingkat/level }\end{array}$ & kekurangan & 1 \\
\hline 4 & 2 & 4,5 & $\begin{array}{l}\text { Kompetensi individu } \\
\text { tingkat/level }\end{array}$ & kelebihan & 2 \\
\hline 5 & -2 & 4 & $\begin{array}{l}\text { Kompetensi individu } \\
\text { tingkat/level }\end{array}$ & kekurangan & 2 \\
\hline 6 & 3 & 3,5 & $\begin{array}{l}\text { Kompetensi individu } \\
\text { tingkat/level }\end{array}$ & kelebihan & 3 \\
\hline 7 & -3 & 3 & $\begin{array}{l}\text { Kompetensi individu } \\
\text { tingkat/level }\end{array}$ & kekurangan & 3 \\
\hline 8 & 4 & 2,5 & $\begin{array}{l}\text { Kompetensi individu } \\
\text { tingkat/level }\end{array}$ & kelebihan & 4 \\
\hline 9 & -4 & 2 & $\begin{array}{l}\text { Kompetensi individu } \\
\text { tingkat / level }\end{array}$ & kekurangan & 4 \\
\hline 10 & 5 & 1,5 & $\begin{array}{l}\text { Kompetensi individu } \\
\text { tingkat/level }\end{array}$ & kelebihan & 5 \\
\hline 11 & -5 & 1 & $\begin{array}{l}\text { Kompetensi individu } \\
\text { tingkat / level }\end{array}$ & kekurangan & 5 \\
\hline
\end{tabular}

5. Menghitung Nilai Akhir:

Nilai Akhir $=60 \% \mathrm{NCI}+40 \% \mathrm{NSI}$

Keterangan:

NCI: nilai rata-rata core factor

NSI: nilai rata-sata secondary factor

Menarik kesimpulan

\subsection{Sensitivitas}

Perhitungan nilai sensitivitas dilakukan untuk mengukur keakuratan suatu nilai. Pencarian nilai sensitivitas dilakukan dengan tiga cara, yaitu [9]:

1. Dilakukan dengan mengurangkan hasil alternatif rekomendasi pertama dengan hasil alternatif rekomendasi kedua, secara umum dirumuskan pada persamaan (5):

Jumlah Sensitivitas $=(\mathrm{Xa}-\mathrm{Xb})$

Keterangan: 
$\mathrm{Xa}=$ nilai alternatif pertama

$\mathrm{Xb}=$ nilai alternatif kedua

2. Penentuan sensitivitas dilakukan dengan membagi hasil alternatif rekomendasi pertama dengan jumlah keseluruhan hasil alternatif. secara umum dirumuskan pada persamaan (6): Jumlah Sensitivitas $=\mathrm{Xi} / \sum \mathrm{X}$

Keterangan:

$\mathrm{Xi} \quad=$ nilai alternatif ke-i

$\sum \mathrm{X}=$ nilai alternatif

3. Penentuan sensitivitas dilakukan dengan menjumlahkan hasil alternatif rekomendasi pertama dengan hasil alternatif rekomendasi kedua, kemudian dibagi dua. Secara umum dirumuskan pada persamaan (7):

Jumlah Sensitivitas $=1 / 2(\mathrm{Xa}+\mathrm{Xb})$

Keterangan:

$\mathrm{Xa}=$ nilai alternatif pertama

$\mathrm{Xb} \quad=$ nilai alternatif kedua

\section{HASIL}

\subsection{Tahap Pengembangan Sistem}

Tahapan pengembangan SPK penentuan SDN rujukan/model mulai dari tahap awal penelitian hingga tercapainya tujuan penelitian dan pengembangan sistem dapat digambarkan dalam bentuk kerangka kerja penelitian, seperti Gambar 1.

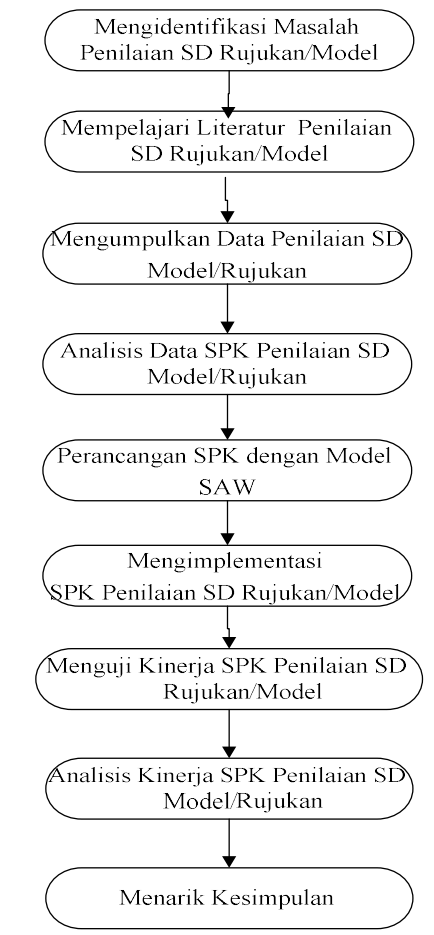

Gambar 1. Kerangka Kerja Penelitian

Kerangka kerja penelitian diawali dengan identifikasi masalah penentuan SDN rujukan/model, studi literatur baik dari media cetak atau elektronik untuk mengumpulkan data yang berkaitan dengan penilaian SD rujukan/model yang selanjutnya dilakukan analisis data. Tahap perancangan terdiri dari desain basis data, antamuka dan perhitungan manual. Tahap implementasi dan pengujian bertujuan untuk menjalankan program dan menguji program dengan mencocokkan hasil program dengan hasil perhitungan masnual, jika hasilnya sama maka program sudah teruji dapat diuji coba penggunaannya. Tahap akhir penelitian adalah menarik kesimpulan dari hasil penelitian dan dianalisis kekurangannya untuk pengembangan penelitian selanjutnya.

\subsection{Perancangan}

Perancangan aplikasi SPK penentuan SDN rujukan/model dibuat berdasarkan pada kebutuahan sistem (input, proses, dan ouput) yang digambarkan dalam bentuk Data Flow Diagram (DFD) Level 0 untuk memperjelas perancangan sistem sebagai Gambar 2.

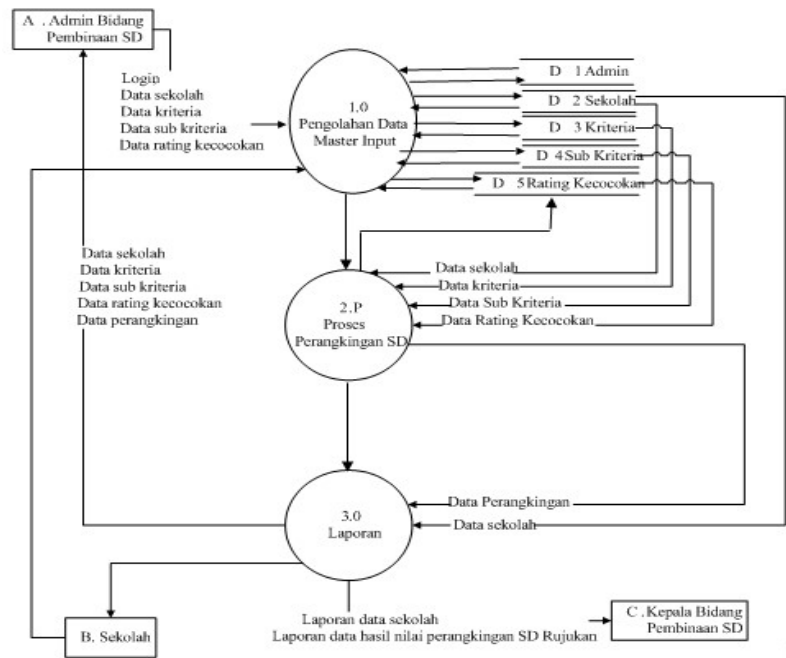

Gambar 2. DFD Level 0

Pada Gambar 2 terdiri dari 3 proses, yaitu: olah data master input, olah data proses perangkingan dengan metode SAW, dan olah data laporan. Entiti yang terlibat adalah: Admin Bidang Pembinaan SD, Sekolah, dan Kepala Bidang Pembinaan SD. Hasil olah data disimpan pada tabel: admin, sekolah, kriteria, sub kriteria, rating kecocokan yang juga merupkan tabel hasil perangkingan.

\subsection{Tahapan Perhitungan Manual Metode $S A W$}

Tahapan perhitungan metode SAW dapat dijelaskan dengan contoh kasus perhitungan manual berikut:

Di Kota Jambi akan dilakukan seleksi terhadap 5 SDN untuk dipilih sebagai SDN rujukan/model, yaitu:

a. $\mathrm{A} 1=\mathrm{SDN} 53 / \mathrm{IV}$,

b. $\mathrm{A} 2=\mathrm{SDN} 069 / \mathrm{IV}$,

c. $\mathrm{A} 3=\mathrm{SDN} 003$,

d. $\mathrm{A} 4=\mathrm{SDN} 017 / \mathrm{IV}$,

e. $\mathrm{A} 5=\mathrm{SDN} 094 / \mathrm{IV}$. 
Langkah penyelesaian:

a. Menentukan kriteria acuan pengambilan keputusan, disajikan pada Tabel 10.

Urutan prioritas kriteria yang akan dijadikan acuan dalam pengambilan keputusan berdasarkan pada kebijakan pengambil keputusan, dapat disajikan dalam bentuk Tabel 11. Dan nilai rating kepentingan setiap kriteria terlihat pada Tabel 12.

Tabel 11. Prioritas Kriteria

\begin{tabular}{cll}
\hline Kriteria $\mathbf{( C j )}$ & \multicolumn{1}{c}{ Nama Kriteria } & Keterangan \\
\hline C1 & Kurikulum & Sangat tinggi \\
C2 & Akreditasi & Sangat tinggi \\
C3 & Prestasi & Sangat tinggi \\
C4 & Indeks UAN dan IIUN & Tinggi \\
C5 & Inovasi & Tinggi \\
C6 & Model & Tinggi \\
C7 & Inovator & Tinggi \\
C8 & Terjangkau & Tinggi \\
\hline
\end{tabular}

Tabel 12. Tingkat Kepentingan setiap kriteria

\begin{tabular}{lcccccccc}
\hline Kriteria & C1 & C2 & C3 & C4 & C5 & C6 & C7 & C8 \\
\hline Rating (\%) & 5 & 5 & 5 & 4 & 4 & 4 & 4 & 4 \\
\hline
\end{tabular}

b. Menentukan rating kecocokan setiap alternatif pada setiap kriteria, merupakan nilai kriteria untuk setiap SDN rujukan/model yang akan diseleksi yang disajikan pada Tabel 13.

Tabel 13. Rating Kecocokan Setiap Alternatif

\begin{tabular}{lllllllll}
\hline Alternatif & C1 & C2 & C3 & C4 & C5 & C6 & C7 & C8 \\
\hline A1 & 100 & 75 & 100 & 75 & 100 & 75 & 75 & 100 \\
A2 & 100 & 75 & 75 & 75 & 75 & 75 & 50 & 75 \\
A3 & 100 & 75 & 75 & 75 & 50 & 75 & 75 & 100 \\
A4 & 100 & 75 & 100 & 75 & 75 & 75 & 75 & 75 \\
A5 & 100 & 75 & 75 & 75 & 50 & 75 & 50 & 75 \\
\hline
\end{tabular}

Keterangan:

Misalkan SDN 53/IV sebagai A1, memiliki kriteria:

i) C1, sudah menerapkan kurikulum 2013

ii) $\mathrm{C} 2$, nilai akreditasi $\mathrm{B}$

iii) $\mathrm{C} 3$, prestasi akademik lebih baik dari pada non akademik

iv) $\mathrm{C} 4$, indeks UAN dan IIUN bernilai $60-80$

v) $\mathrm{C} 5$, memiliki pratek baik dan inovasi pendidikan dengan nilai $80-100$

vi) C6, belum pernah menjadi SDN model

vii) $\mathrm{C} 7$, kesediaan memberikan pengimbasan praktik baik dan inovasi pendidikan yang dimiliki ke sekolah lain (Inovator) dengan nilai $60-80$

viii) $\mathrm{C} 8$, keterjangkauan SDN sedang, dekat pusat kota.

c. Membuat matrik keputusan, berdasarkan langkah b. Tabel 12 .

$$
x_{i j}=\left\{\begin{array}{cccccccc}
100 & 75 & 100 & 75 & 100 & 75 & 75 & 100 \\
100 & 75 & 75 & 75 & 75 & 75 & 50 & 75 \\
100 & 75 & 75 & 75 & 50 & 75 & 75 & 100 \\
100 & 75 & 100 & 75 & 75 & 75 & 75 & 75 \\
100 & 75 & 75 & 75 & 50 & 75 & 50 & 75
\end{array}\right\}
$$

d. Melakukan normalisasi matrik x, sesuai dengan rumus (1)
Dikarenakan semua kriteria adalah benefit, maka gunakan nilai maksimum dari setiap kriteria. Berdasarkan langkah c. Nilai maksimum $\mathrm{x}_{\mathrm{ij}}$ terlihat pada Tabel 14:

Tabel 14. Nilai Maksimum $\mathrm{x}_{\mathrm{ij}}$

\begin{tabular}{llllllll}
\hline C1 & C2 & C3 & C4 & C5 & C6 & C7 & C8 \\
\hline 100 & 75 & 100 & 75 & 100 & 75 & 75 & 100 \\
\hline
\end{tabular}

Maka, nilai normalisasi matriks adalah sebagai berikut:

$$
r_{i j}=\left\{\begin{array}{cccccccc}
1 & 1 & 1 & 1 & 1 & 1 & 1 & 1 \\
1 & 1 & 0,75 & 1 & 0,75 & 1 & 0,67 & 0,75 \\
1 & 1 & 0,75 & 1 & 0,5 & 1 & 1 & 1 \\
1 & 1 & 1 & 1 & 0,75 & 1 & 1 & 0,75 \\
1 & 1 & 0,75 & 1 & 0,50 & 1 & 0,67 & 0,75
\end{array}\right\}
$$

contoh:

$$
\begin{aligned}
& r_{11}=x_{11} / \max C 1=100 / 100=1 \\
& r_{23}=x_{23} / \max C 3=75 / 100=0.75
\end{aligned}
$$

e. Menghitung nilai prefersni setiap alternatif (proses perankingan) dengan rumus (2). Nilai preferensi merupakan penjumlahan dari perkalian bobot kepentingan pada Tabel 12 dengan nilai normalisasi dari langkah $\mathrm{d}$.

$$
\begin{aligned}
\mathrm{V}_{1}= & (5 * 1)+(5 * 1)+(5 * 1)+(4 * 1)+(4 * 1)+(4 * 1)+ \\
& (4 * 1)+(4 * 1)=35 \\
\mathrm{~V}_{2}= & (5 * 1)+(5 * 1)+(5 * 0,75)+(4 * 1)+(4 * 0,75)+(4 * 1)+ \\
& (4 * 0,67)+(4 * 0,75)=30,42 \\
\mathrm{~V}_{3}= & (5 * 1)+(5 * 1)+(5 * 0,75)+(4 * 1)+(4 * 0,5)+(4 * 1)+ \\
& (4 * 1)+(4 * 1)=31,75 \\
\mathrm{~V}_{4}= & (5 * 1)+(5 * 1)+(5 * 1)+(4 * 1)+(4 * 0,75)+(4 * 1)+ \\
& (4 * 1)+(4 * 0,75)=33 \\
\mathrm{~V}_{5}= & (5 * 1)+(5 * 1)+(5 * 0,75)+(4 * 1)+(4 * 0,5)+(4 * 1)+ \\
& (4 * 0,67)+(4 * 0,75)=29,42
\end{aligned}
$$

f. Pengambilan keputusan, berdasarkan hasil langkah e. Diperoleh hasil perhitungan nilai preferensi tertinggi adalah SDN 53/IV dengan nilai 35. Maka dapat disimpulkan, bahwa dari 5 SDN yang diseleksi, maka SDN yang akan dijadikan tujukan/model di Kota Jambi adalah SDN 53/IV Jambi.

\section{PEMBAHASAN}

\subsection{Implementasi Sistem}

Pada tahap implementasi, sistem aplikasi SPK penentuan SDN rujukan/model dibangun dengan pemrograman PHP yang terkoneksi dengan database MySQL.

\subsubsection{Tampilan Kebutuhan Input Data}

a. Tampilan Olah Data Sekolah

Tampilan Gambar 3. berfungsi untuk memanipulasi data SDN di Kota Jambi yang akan diseleksi sebagai variabel alternatif. 


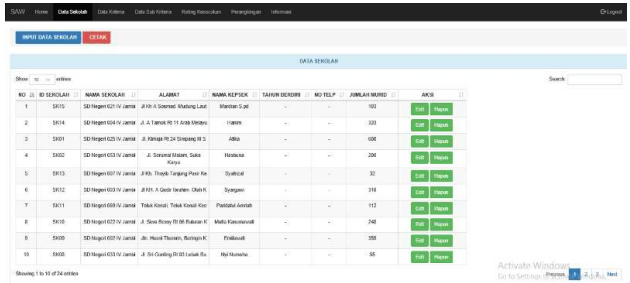

Gambar 3. Tampilan Olah Data Sekolah

b. Tampilan Olah Data Kriteria

Tampilan Gambar 4. berfungsi untuk memanipulasi data variabel kriteria sebagai dasar penilaian SDN rujukan/model. Variabel kriteria yang baru dapat ditambah jika ada kebijakan baru dari pengambil keputusan.

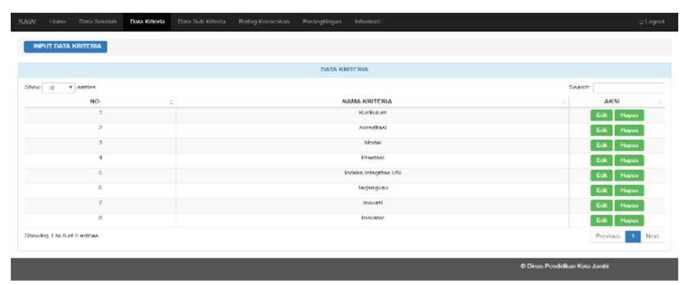

Gambar 4. Tampilan Olah Data Kriteria

c. Tampilan Olah Data Sub Kriteria

Tampilan Gambar 5. berfungsi untuk memanipulasi data variabel sub kriteria. Sama halnya dengan kriteria, sub kriteria baru juga dapat ditambahkan.

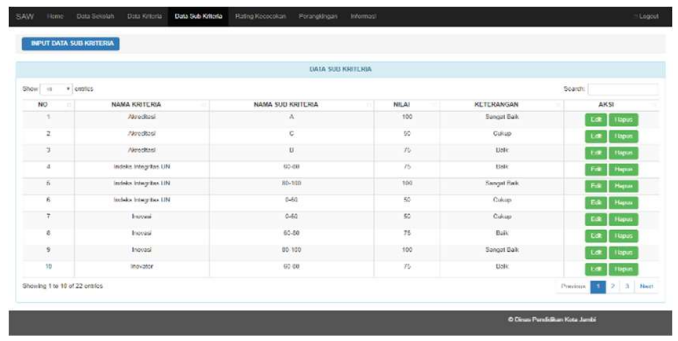

Gambar 5. Tampilan Olah Data Sub Kriteria d. Tampilan Olah Data Rating Kecocokan

Tampilan Gambar 6. berfungsi untuk olah data rating kecocokan, yaitu data kriteria setiap SDN di Kota Jambi yang akan diseleksi.

Data ini sesuai dengan data yang dimiliki SDN masing-masing.

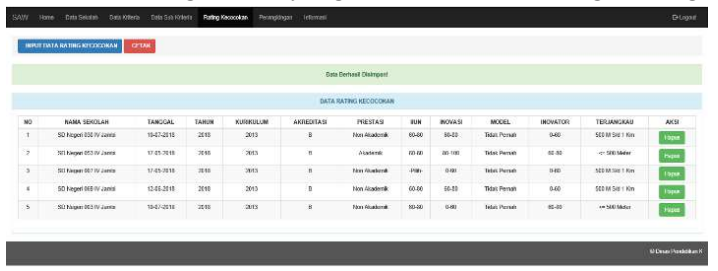

Gambar 6. Tampilan Olah Data Rating Kecocokan

e. Tampilan Olah Data Bobot Kepentingan

Tampilan Gambar 7. berfungsi untuk input data bobot kepentingan setiap kriteria sesuai dengan kebijakan pengambil keputusan.

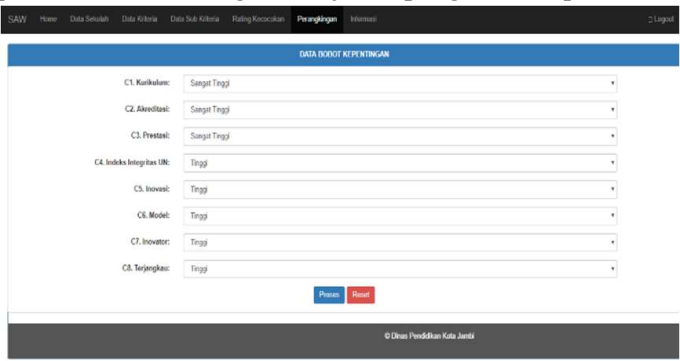

Gambar 7. Tampilan Olah Data Bobot Kepentingan

f. Tampilan Hasil Proses Perhitungan

Tampilan Gambar 8., 9., dan 10 berfungsi untuk menampilan hasil proses perhitungan dengan metode SAW. Terdiri dari tampilan data nilai rating kecocokan, matrik keputusan, normalisasi matriks, nilai preferensi (hasil proses perhitungan), dan tampilan hasil perangkirangan dalam bentuk grafik.

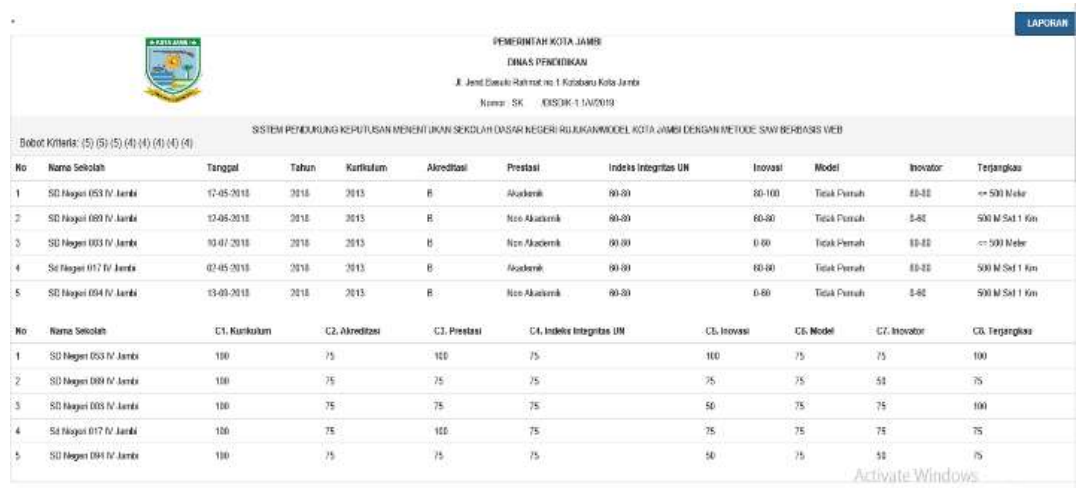

Gambar 8. Tampilan Rating Kecocokan dan Matrik Keputusan 


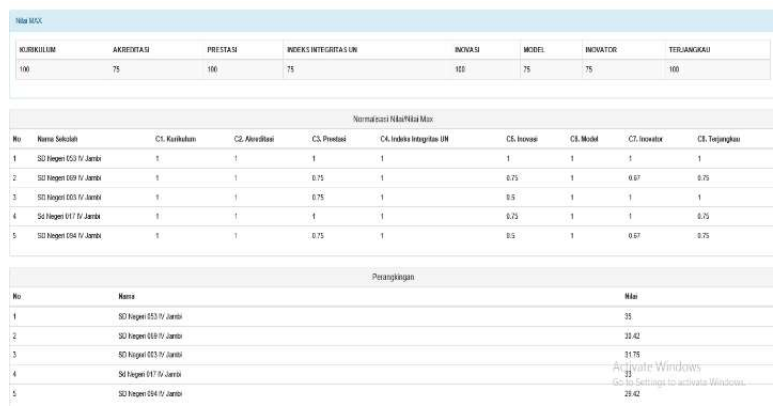

Gambar 9. Tampilan Normalisasi Matrik dan Hasil Perangkingan

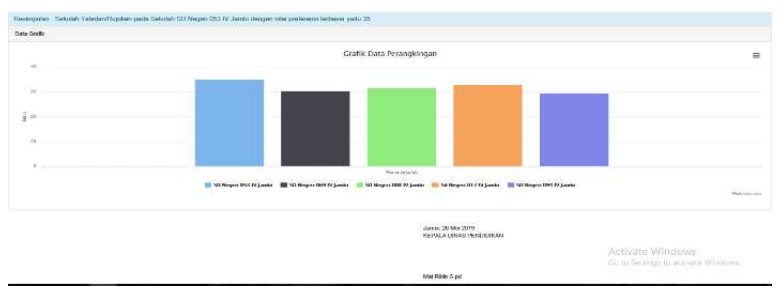

Gambar 10. Tampilan Hasil Perangkingan Dalam Bentuk Grafik g. Tampilan Laporan Data Kriteria Per Sekolah

Tampilan Gambar 11. berfungsi untuk menampilkan laporan data rating kecocokan setiap sekolah terhadap setiap kriteria.

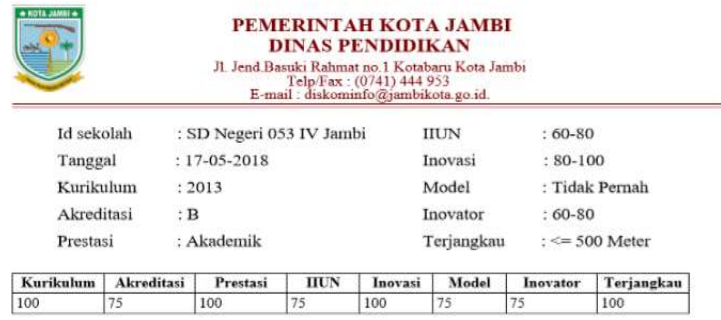

Gambar 11. Laporan Data Kriteria Per Sekolah

\subsubsection{Hasil Implementasi Sistem}

Berdasarkan proses implementasi, maka hasil perangkingan dari proses seleksi penentuan SDN rujukan/model terlihat nilai tertinggi dicapai oleh SDN 53/IV Kota Jambi. Selanjutnya SDN yang direkomendasikan untuk dijadikan SDN rujukan/model adalah SDN 53/IV Kota Jambi.

Jika diinginkan lebih dari satu SDN (misal: 3 SDN) yang akan dipilih menjadi sekolah rujukan/model, maka pengambil keputusan dapat memilih berdasarkan 3 nilai tertinggi yang dapat dilihat pada Gambar 9. Adapun 3 SDN tersebut adalah: SDN 53/IV (nilai 35), SDN 17/IV (nilai 33), dan SDN 003 (nilai 31,75).

\subsection{Evaluasi dan Analisis Sistem}

Pada tahap evaluasi hasil, dilakukan perbandingan hasil terhadap sistem aplikasi, jika ada perubahan data bobot kepentingan atau prioritas kriteria yaitu seperti terlihat pada Tabel 15 dan Tabel 16.
Tabel 15. Prioritas Kriteria

\begin{tabular}{cll}
\hline Kriteria $\mathbf{( C j )}$ & \multicolumn{1}{c}{ Nama Kriteria } & \multicolumn{1}{c}{ Keterangan } \\
\hline C1 & Kurikulum & Sangat Tinggi \\
C2 & Akreditasi & Tinggi \\
C3 & Prestasi & Sangat Tinggi \\
C4 & Indeks UAN dan IIUN & Tinggi \\
C5 & Inovasi & Tinggi \\
C6 & Model & Tinggi \\
C7 & Inovator & Sangat Tinggi \\
C8 & Terjangkau & Tinggi \\
\hline
\end{tabular}

Tabel 16. Bobot Tingkat Kepentingan Setiap Kriteria

\begin{tabular}{lcccccccc}
\hline Kriteria & C1 & C2 & C3 & C4 & C5 & C6 & C7 & C8 \\
\hline Rating (\%) & 5 & 4 & 5 & 4 & 4 & 4 & 5 & 4 \\
\hline
\end{tabular}

Maka hasil proses seleksi penentuan SDN rujukan/model adalah sebagai Gambar 13 dan Gambar 14. Menunjukkan hasil perngkingan yang sama, yaitu SDN yang direkomendasikan menjadi SDN rujukan/model adalah SDN 53/IV Kota Jambi. Jika diinginkan 3 SDN yang direkomendasikan untuk dijadikan SDN Rujukan/Model, maka 3 SDN peringkat teratas juga menunjukkan hasil yang sama, yaitu: SDN 53/IV (nilai 35), SDN 17/IV (nilai 33), dan SDN 003 (nilai 31,75).

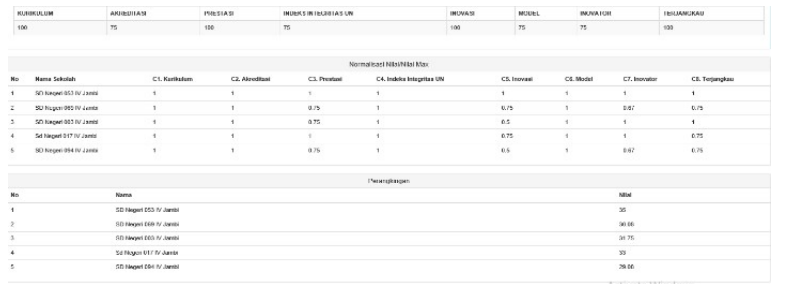

Gambar 13. Hasil Perangkingan Perubahan Prioritas Kriteria (1)

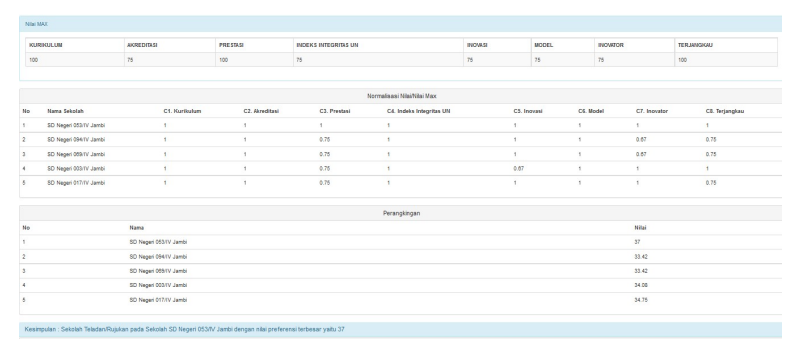

Gambar 14. Hasil Perangkingan Perubahan Prioritas Kriteria (2)

Perbandingan hasil perhitungan dari perbedaan prioritas kriteria adalah seperti pada Tabel 17.

Tabel 17. Perbandingan Hasil

\begin{tabular}{cccc}
\hline $\begin{array}{c}\text { Prioritas } \\
\text { Kriteria }\end{array}$ & $\begin{array}{c}\text { C1, C2, C3: } \\
\text { Sangat } \\
\text { Tinggi }\end{array}$ & $\begin{array}{c}\text { C1, C3, C7 } \\
\text { Sangat } \\
\text { Tinggi (1) }\end{array}$ & $\begin{array}{c}\text { C1, C2, C5, } \\
\text { C6 Sangat } \\
\text { Tinggi (2) }\end{array}$ \\
\hline SDN 053/IV & $\mathbf{3 5}$ & $\mathbf{3 5}$ & $\mathbf{3 7}$ \\
SDN 069/IV & 30.42 & 30.08 & 33.42 \\
SDN 003/IV & 31.75 & 31.75 & 34.08 \\
SDN 017/IV & 33 & 33 & 34.75 \\
SDN 094/IV & 29.42 & 29.08 & 33.42 \\
\hline
\end{tabular}


Berdasarkan hasil perubahan prioritas kriteria, diperoleh hasil yang tidak jauh berbeda, hal tersebut menunjukkan bahwa perubahan prioritas kriteria tidak terlalu mempengaruhi hasil perangkingan, yaitu SDN 053/IV masih tetap yang terpilih sebagai SDN rujukan/model dan SDN 017 sebagai peringkat ke kedua yang direkomendasikan sebagai SDN rujukan/model.

Selanjutnya, jika dilakukan perubahan data kriteria pada salah satu alternatif yaitu SDN 053/IV dengan menggunakan prioritas kriteria yang sama yaitu: C1, C2, C5, C6 Sangat Tinggi, dan C3, C4, C7, C8 Tinggi, maka diperoleh hasil perangkingan seperti Tabel 18.

Tabel 18. Perbandingan Hasil

\begin{tabular}{lcc}
\hline $\begin{array}{c}\text { Alternatif/ SDN } \\
\text { Yang Diseleksi }\end{array}$ & $\begin{array}{c}\text { Hasil } \\
\text { Perangkingan } \\
\text { Data 1 }\end{array}$ & $\begin{array}{c}\text { Hasil } \\
\text { Perangkingan } \\
\text { Data 2 }\end{array}$ \\
\hline SDN 053/IV & $\mathbf{3 5}$ & 34 \\
\hline SDN 094/IV & 29 & 34.67 \\
\hline SDN 069/IV & 33.42 & 34.67 \\
\hline
\end{tabular}

\begin{tabular}{lcc}
\hline SDN 003/IV & 31.75 & 35.33 \\
\hline SDN 017/IV & 33 & $\mathbf{3 6}$ \\
\hline
\end{tabular}

Terlihat bahwa pada hasil perangkingan dengan menggunakan data 1 , SDN yang direkomendasikan sebagai SDN rujukan/model adalah SDN 053/IV. Sedangkan hasil perangkingan dengan menggunakan data 2, SDN yang direkomendasikan sebagai SDN rujukan/model adalah SDN 017/IV.

Dari hasil perangkingan jika dicoba dengan prioritas kriteria yang sama dengan mengubah nilai kriteria atau data kriteria yang berbeda, dapat disimpulkan bahwa perubahan data kriteria dari setiap alternatif sangat mempengaruhi hasil perangkingan.

Untuk mengukur keakuratan suatu nilai, dapat dihitung menggunakan sensitivitas dengan rumus (3), (4), dan (5) dapat dilihat pada tabel 19.

Tabel 19. Perbandingan Hasil Sensitivitas

\begin{tabular}{ccc}
\hline Sensitivitas & $\begin{array}{c}\text { Hasil } \\
\text { Perangkingan Data 1 }\end{array}$ & $\begin{array}{c}\text { Hasil } \\
\text { Perangkingan Data 2 }\end{array}$ \\
\hline Cara 1 & $35-33.42=1.58$ & $36-35.33=0.67$ \\
\hline Cara 2 & $35 /(35+29.42+33.42+31.75+33)=0.215$ & $36 /(34+34.67+34.67+35.33+36)=0.206$ \\
\hline Cara 3 & $(35+33.42) / 2=34.21$ & $(36+35.33) / 2=35.662$ \\
\hline Rata-rata & 12.001 & 12.179 \\
\hline
\end{tabular}

Berdasarkan hasil perbandingan perhitungan nilai sensitivitas perangkingan data 1 dan perangkingan data 2 pada Tabel 18 dengan menggunakan ketiga rumus sensitivitas, maka dapat disimpulkan bahwa: Hasil perhitungan Perangkingan Data 1 dapat dijadikan acuan dalam pengambilan keputusan, dikarenakan hasil rata-rata nilai sensitivitasnya lebih kecil dibandingkan Hasil Perangkingan Data 2, yaitu:12.001. Semakin kecil nilai sensitivitas, maka pengambilan keputusan semakin baik.

\section{KESIMPULAN}

Berdasarkan hasil penelitian di atas, maka dapat disimpulkan sebagai berikut: Aplikasi ini dapat digunakan sebagai alat bantu yang dapat memudahkan pihak Dinas Pendidikan Kota Jambi dalam melakukan proses seleksi SDN rujukan/model; Penggunaan metode SAW dapat diterapkan dengan baik pada aplikasi ini, karena salah satu keunggulan metode SAW yaitu pada kemampuannya untuk melakukan penilaian secara lebih tepat karena didasarkan pada nilai kriteria dan bobot preferensi yang sudah ditentukan, selain itu SAW juga dapat menyeleksi alternatif terbaik dari sejumlah alternatif yang ada karena adanya proses perangkingan setelah menentukan bobot untuk setiap kriteria

Perubahan prioritas kriteria tidak terlalu mempengaruhi hasil perangkingan seperti pada Tabel 16. yang memberikan hasil keputusan yang sama, yaitu SDN 053/IV terpilih sebagai SDN rujukan/model. Perangkingan sangat dipengaruhi oleh nilai kriteria setiap alternatif. Semakin baik nilai kriteria suatu alternatif, maka semakin tinggi peringkat perangkingan; Perubahan terhadap data kriteria dari alternatif (SDN) dengan tetap menggunakan prioritas kriteria yiang sama, maka akan memberikan hasil perangkingan yang cenderung berbeda. Nilai kriteria setiap alternatif akan mempengaruhi hasil perangkingan. Sehingga dengan aplikasi ini penentuan SDN rujukan/model lebih objektif dan tepat sasaran.

Penelitian ini masih memiliki kekurangan, yaitu: hasil perangkingan belum ditampilkan terurut dari nilai tertinggi, hal ini tetntu saja akan mengalami kesulitan jika data SDN yang diseleksi lebih banyak, maka untuk pengembangan penelitian selanjutnya perlu diurutkan dari nilai tertinggi sehingga pengambil keputusan lebih mudah menetukan SDN rujukan/model.

\section{DAFTAR PUSTAKA}

[1] Uny, "Bab 1 Pendahuluan", Internet: http://eprints.uny.ac.id /9797/1/BAB\%201\%20-08108241051.pdf, [Nov, 02, 2019].

[2] Saifuddin, Abdullah, "SPK Pembinaan dan Pengembangan Sekolah Model (Studi Kasus Kecamatan Kempas)", Sistemasi, Vol 6 Nomor 2, pp. 45-55, 2017.

[3] Agus Supriyadi, "Sistem Penunjang Keputusan Pemilihan Sekolah Dasar Terbaik Dengan Metode Simple Additive Weighting (SAW) (Studi Kasus : Unit Pelaksana Teknis Daerah (UPTD) Kecamatan Cilandak)", Skripsi, Digital 
Reporsitory Universitas Pamulang, Tangerang Selatan, Apr. $18,2019$.

[4] Febri Ariyanto, Muhamad Muslihudin, "Sistem Pendukung Keputusan Menentukan Sekolah Menengah Kejuruan (SMK) Unggulan Di Wilayah Lampung Tengah Menggunakan Metode Topsis", TAM (Technology Acceptance Model), Vol. 5, pp. 1-8, Desember 2015.

[5] Herlinda K., "Mengenal Sistem Pendukung Keputusan", Internet: http://news.palcomtech.com/2014/03/mengenalsistem-pendukung-keputusan/, March 21, 2014 [Okt. 10, 2019].

[6] Utomo Meriano S.D (2015). "Penerapan Metode SAW (Simple Additive Weight) Pada Sistem Pendukung Keputusan Untuk Pemberian Beasiswa Pada SMA Negeri 1 Cepu Jawa Tengah”, Skripsi, Udinus Repository, Apr. 29, 2015.

[7] Azid Zainuri, "8 Kriteria Untuk Menjadi Sekolah Rujukan", Internet: https://www.azid45.web.id/2018/07/8-kriteria-untukmenjadi-sekolah-rujukan.html?m=1, July 08, 2018 [Oct. 15, 2019].

[8] Muchsam Yoki, dkk. "Penerapan Gap Analysis Pada Pengembangan Sistem Pendukung Keputusan Penilaian Kinerja Karyawan (Studi Kasus PT.XYZ)", Seminar Nasional Aplikasi Teknologi Informasi 2011 (SNATI 2011) Yogyakarta 2011, pp A-94-A-100.

[9] R. D. Kusmiyanti, Suliatun, dan Mustakim, "Analisis Sensitifitas Model SMART-AHP dengan SMARTER-ROC sebagai Pengambilan Keputusan Multi Kriteria Seminar Nasional Teknologi Informasi”, SNTIKI 9 UIN Sultan Syarif Kasim Riau Pekanbaru, Mei 2017 Internet: http://ejournal.uinuska.ac.id/index.php/SNTIKI/ article/view/3266/2155, Mei 2017 [Sept 07, 2019].

[10] Wedhasmara A. Dan Wibowo J. A., "Sistem Pendukung Keputusan Pemilihan Pembelian Kendaraan Bermotor Dengan Metode SAW", Jurnal Sistem Informasi (JSI), Vol 2, No. 2, pp. 246-257, Oktober 2010.

[11] Situmorang H, "Sistem Pendukung Keputusan Pemilihan Calon Peserta Olimpiade Sains Tingkat Kabupaten Langkat Pada Madrasah Aliyah Negeri (MAN) 2 Tanjung Pura Dengan Menggunakan Metode Simple Additive Weihgting (SAW)", Jurnal TIMES, Vol IV No. 2, pp. 24-30, 2015.

[12] Kahar Novhirtamely, Nurhayati, "Penentuan Pemilihan Supplier Dengan Metode Simple Additive Weighting (SAW) di Aston Jambi Hotel \& Conference Center", Jurnal Akademika, Vol. 11, No. 2, pp. 45-50, April 2019

[13] Kahar Novhirtamely, Branata F. Y., "Penggunaan Metode Analytical Hierarchy Process (AHP) Dalam Penentuan Lokasi Prioritas Pembangunan Drainase Di Kota Jambi", Jurnal Akademika, Vol. 11 No. 1, pp 23-28, November 2018.

[14] Aminuddin F. H., Sany E., Kahar Novhirtamely, "Sistem Pendukung Keputusan Penentuan Minat dan Bakat Siswa Pada SMKN 2 Muaro Jambi”, Vol. 12, No. 1, pp 8-13, November 2019.

[15] Wijanarto, M. "Sistem Pendukung Keputusan Pemilihan Objek Wisata Dan Hotel Di Daerah Istimewa Yogyakarta Dengan Metode Fuzzy Mcdm Berbasis Android", Internet: http://mahasiswa.dinus.ac.id/docs/skripsi/jurnal/14684.pdf, [2011].

[16] Kahar, Novhirtamely. "Penerapan Metode Fuzzy Multicriteria Decision Making Untuk Seleksi Penerima Bantuan Rumah Layak Huni (Studi Kasus Di Desa Singkawang Jambi)", Sebatik, Vol. 23 No.1, pp. 124-131, Juni 2019.

[17] Kahar, Novhirtamely. "Sistem Pendukung Keputusan Penerima Jamkesmasda Di Kota Jambi." Konferensi Nasional Informatika 2013. 2013.

[18] Kahar, Novhirtamely dan Sitompul E. A., "Sistem Pendukung Keputusan Penerima Bantuan Dana Unit Kegiatan Mahasiswa (UKM) Stmik Nurdin Hamzah Jambi”, Seminar Nasional Informatika 2013, pp 153.

\section{NOMENKLATUR}

\begin{tabular}{|c|c|}
\hline $\mathrm{r}_{\mathrm{ij}}$ & $\begin{array}{l}\text { : rating kinerja ternormalisasi, dari alternatif } A_{i} \text { pada } \\
\text { atribut } C_{j} ; i=1,2, \ldots m \text { dan } j=1,2, \ldots, n \text {. }\end{array}$ \\
\hline $\operatorname{Max} \mathrm{x}_{\mathrm{ij}}$ & : nilai maksimum dari setiap baris dan kolom \\
\hline $\operatorname{Min} \mathrm{x}_{\mathrm{ij}}$ & : nilai minimum dari setiap baris dan kolom \\
\hline $\mathrm{x}_{\mathrm{ij}}$ & : baris dan kolom dari matriks \\
\hline $\mathrm{V}$ & : Nilai akhir dari alternatif \\
\hline & : Bobot yang telah ditentukan \\
\hline
\end{tabular}

\section{BIODATA PENULIS}

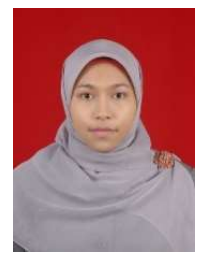

Novhirtamely Kahar

adalah dosen tetap Program Studi Teknik Informatika STMIK Nurdin Hamzah Jambi. Penulis menempuh pendidikan S1 di jurusan Teknik Informatika Universitas Islam Indonesia (UII) Yogayakarta dan pendidikan S2 di jurusan Teknologi Informasi UPI YPTK Padang dengan spesialisasi Sistem Cerdas. Penelitian yang pernah penulis lakukan diantaranya bertema: Metode Numerik, Teori Bahasa Automata, SPK, Data Mining, Logika Fuzzy, Jaringan Syaraf Tiruan. Selama bekerja di STMIK Nurdin Hamzah Jambi pernah menjabat sebagai Sekretaris Program Studi Teknik Informatika dan saat ini sebagai Ketua Program Studi Teknik Informatika STMIK Nurdin Hamzah. Matakuliah yang pernah diampu diantaranya: Kecerdasan Buatan, Metode Numerik, Teori Bahasa Automata, Jaringan Syaraf Tiruan, Pemrograman Delphi. 